\title{
THE IMPLEMENTATION OF IRON SUPPLEMENTATION AND ANTENATAL COUNSELING FOR IRON DEFICIENCY ANEMIA IN PREGNANCY
}

\author{
Darmawati1, Teuku Tahlil $^{2}$, Toungku Nizwan Siregar ${ }^{3}$, Hajjul Kamil ${ }^{4}$, and \\ Masyithah Audina ${ }^{5}$
}

1. Maternity Nursing Department, Faculty of Nursing, Syiah Kuala University Darussalam / Doctoral Student of Mathematic and Applied Science Syiah Kuala University Darussalam

2. Community Nursing Department, Faculty of Nursing, Syiah Kuala University

3. Faculty of Veterinary, Syiah Kuala University Darussalam

4. Management Nursing Department, Faculty of Nursing, Syiah Kuala University Darussalam

5. Student of Nursing Faculty, Syiah Kuala University Darussalam

\begin{abstract}
Anemia is one of the conditions that leads to maternal mortality in Indonesia. The Indonesian Ministry of Health has tried to reduce it through an antenatal program conducted at public health centers, with several indicators including iron supplementation and antenatal counseling. This study was a correlative study with a cross sectional approach carried out between February and June 2018. The population was 1,285 pregnant women with 102 samples recruited using a purposive sampling technique. Blood hemoglobin levels were examined using a $\mathrm{Hb}$ meter. Data collection were carried out through guided interviews about iron supplementation and the antenatal counseling that had been received. The antenatal counseling was done by nurses according to Ministry of Health guidelines and was carried out at the first visit. Data analysis was done using the Pearson Product Moment Test. The implementation of iron supplementation and antenatal counseling was implemented comprehensively $(51.0 \% ; 64.7 \%$ respectively). This study showed that there was a relationship between iron supplementation and iron deficiency anemia (0.000) and there was no relationship between antenatal counseling and iron deficiency anemia (0.172). Antenatal providers are recommended to improve the service provided, especially the iron supplementation, which should be accompanied by giving information through antenatal counseling, so that the high maternal mortality rates can be rectified immediately.
\end{abstract}

Key words: Anemia, Counseling, Information, Supplementation, Iron

\section{ABSTRAK}

Anemia merupakan salah satu kondisi yang berkontribusi terhadap mortalitas ibu di Indonesia. Kementerian Kesehatan Indonesia berupaya untuk menurunkan angka ini melalui program pelayanan antenatal yang dilakukan di puskesmas dengan indikator termasuk suplementasi zat besi dan konseling antenatal. Penelitian ini merupakan penelitian korelatif dengan pendekatan cross sectional yang dilakukan pada Februari sampai Juni 2018. Populasi dalam penelitian ini adalah 1,285 orang ibu hamil dengan sampel 102 orang yang direkrut menggunakan teknik purposive sampling. Kadar hemoglobin darah diperiksa menggunakan $\mathrm{Hb}$ meter. Pengumpulan data dilakukan menggunakan wawancara terpimpin. Analisa data dilakukan menggunakan uji Pearson Product Moment. Pelaksanaan suplementasi zat besi dan konseling antenatal telah terlaksana secara terpadu $(51.0 \%$; 64.7\%, masingmasing). Penelitian ini menunjukkan bahwa terdapat hubungan antara suplementasi zat besi dan anemia defisiensi zat besi $(0.000)$ dan tidak terdapat hubungan antara konseling antenatal dan anemia defisiensi zat besi (0.172). Diharapkan kepada penyedia layanan antenatal untuk dapat meningkatkan kualitas pelayanan yang diberikan, termasuk suplementasi zat besi yang dibarengi dengan penyediaan informasi melalui konseling antenatal sehingga angka mortalitas ibu akibat anemia defisiensi zat besi dapat ditangani segera.

Kata Kunci: Anemia, Konseling, Informasi, Suplementasi, Zat Besi 


\section{BACKGROUND}

The maternal mortality rate is an important indicator for measuring standards of maternal health in a region (Chhabra, 2014). Maternal mortality rates in Indonesia are still relatively high, with 305 per 100,000 live births in 2015 (Kemenkes RI, 2016). In Aceh Besar District, the mortality rate is 88 per 100,000 live births, which makes this region one of the districts with the highest rate of maternal mortality in Aceh Province (Dinas Kesehatan Kabupaten Aceh Besar, 2016). This number is still far from the target set out in Sustainable Development Goals (SDGs) which seeks to reduce maternal mortality rates to less than 70 per 100,000 live births by 2030 (Inter-Agency and Expert Group on SDG Indicators, 2016).

Anemia in pregnancy is one of the conditions which contributes to maternal mortality and affects 32 million pregnant women worldwide (Daru et al., 2018). The most common type of anemia in pregnancy is iron deficiency anemia, which is also the underlying cause in $50 \%$ of all cases of anemia. Iron deficiency results from a combination of increased demand and decreased intake or absorption. Iron deficiency that remains untreated for a long time will become iron deficiency anemia (Clarke \& Dodds, 2014). Although anemia is readily treatable, various studies show that anemia is associated with severe adverse maternal and perinatal outcomes, including low birth weight, premature birth and perinatal death. Screening for iron deficiency anemia results in early identification and earlier treatment so it can prevent serious negative outcomes (Cantor et al., 2015).

In Indonesia, the percentage of pregnant women who suffer from anemia was $37.1 \%$, while in Aceh Besar District in 2017 the percentage was the same as the national (Kemenkes RI, 2013). The total number of pregnant women in Aceh Besar District in 2017 was 8,478 pregnant women and 3,145 of them had anemia. The highest number was in the work area of the Darul Imarah Public Health Center, which was 517 cases from a total of 1,285 pregnant women (Dinas Kesehatan

Kabupaten Aceh Besar, 2016).

Seeing the high incidence of anemia in pregnancy and the rate of maternal mortality, the government of Indonesia through the Ministry of Health has made various efforts to reduce this condition. One of them was through an integrated antenatal care program that has seen many improvements year after year. Provision of integrated antenatal care should be offered with good quality services in accordance with government standards. During this time, there were many pregnant women who did not receive antenatal care at primary health services (due to missed opportunities), which meant they were not exposed to comprehensive and integrated antenatal care (Kemenkes RI, 2010).

One of the steps in an integrated antenatal care program that conceptually can overcome the condition of anemia is by giving iron supplements. This supplementation is usually given in tablet form with ferrous sulphate type tablets (200 mg per tablet containing $67 \mathrm{mg}$ of iron). In primary health centers, every pregnant woman is recommended to consume iron tablets - at least 90 tablets during pregnancy, which are provided from the first contact with the woman (Kemenkes RI, 2010). This is important because diet alone is insufficient to meet the daily iron level required by the mother and the fetus - therefore they need additional iron through tablet supplements (Vir, 2011).

However, iron tablet consumption has side effects for the mothers who consume it, including nausea, vomiting, diarrhea, and/or constipation which makes pregnant women unwilling to consume the tablets (Porwit, McCullough, \& Erber, 2011; Sivanganam \& Weta, 2017). This situation should be followed up by the implementation of antenatal counseling so that the mothers understand the importance of consuming iron tablets and how to deal with perceived side effects. This is as well as some mandatory indicators recommended by the Indonesian Ministry of Health to be delivered to pregnant women. 
Antenatal counselling is part of integrated antenatal care which is provided from the first contact to help pregnant women to solve their problems. Some of the information conveyed includes: maternal health, healthy lifestyle, husband's role, danger signs in pregnancy, balanced nutrition, infectious and non-communicable diseases, exclusive breastfeeding, postpartum family planning, and immunization. Counseling in antenatal care is done face-to-face between pregnant women and health workers so that mothers have the opportunity to ask questions and discuss issues related to their pregnancies (Kemenkes RI, 2010)

Based on the interviews conducted with health workers at Darul Imarah Public Health Center, it was found that they had implemented the antenatal care program for pregnant women who visited the service. However, $80 \%$ of pregnant women attending antenatal care at that public health center said that the counseling was not carried out at each visit, only at the first visit (K1). Based on these findings, the researchers are interested to examine the relationship between the administration of iron supplementation and the implementation of antenatal counseling with regard to levels of iron deficiency anemia in the Darul Imarah Public Health Center, Aceh Besar District, Aceh Province.

This study is different from previous studies that have been conducted because we tried to assess the relationship between government programs that have been applied so far with the incidence of iron deficiency anemia in order to find out if there are any significant impacts from the government program regarding the incidence of iron deficiency anemia.

\section{METHODS}

This research was a correlative study with a cross sectional approach design. The population of this study were all pregnant women who visited integrated antenatal care at Darul Imarah Public Health Center, Aceh Besar District, which was 1,285 people in total. The study was conducted between February and June 2018.

The calculation of samples was done using the Slovin formula that recruited participants using a purposive sampling technique. The inclusion criteria in this study were: Pregnant women who had more than once visited integrated antenatal care at the Darul Imarah Health Center in Aceh Besar District, second and third trimester pregnancies, and had no circulation problems or blood disorders. The sample number in this study was 102 pregnant women. Data collection techniques were carried out by guided interviews based on questionnaires developed by the researchers. The questions asked in the questionnaire were made based on the guidelines of the Kemenkes RI (2010), which were the following:

Table 1 The questionnaire questions used for pregnant women visiting the antenatal care at Darul Imarah Health Center, Aceh Besar

The implementation of iron
supplementation

- Have the health workers given 30 tablets of iron every 3 months during this current pregnancy?

- Do the health workers provide information about the substances contained in the iron tablet that are consumed by the mother?

- Do the health workers provide information about when to take the iron tablets that are given to the mother?

- Do the health workers provide information about the benefits of consuming iron tablets for maternal health during pregnancy?

- Do the health workers provide information about foods that can increase the absorption of iron tablets?

- Do the health workers provide information about food that inhibits the absorption of iron tablets?

- Do the health workers provide information about the side effects of consuming iron tablets?

\section{Antenatal counselling}

- Have the health providers ever advised the mother to have a regular 
pregnancy checkup?

- Did the health workers ever advise the mother to get enough rest $(9-10$ hours per day)?

- Did the health workers ever advise the mother about how to clean themselves properly (such as washing your hands before eating, taking a bath twice a day, or brushing your teeth)?

- Did the health workers ever advise the mother to do light exercise?

- Did the health workers ever explain the role of the husband in the pregnancy (such as supporting the pregnancy process, preparation for labor, and their role in complications)?

- Did the health workers ever explain about balanced nutrition during the mother's pregnancy at this time (such as the importance of meeting the daily required intake of protein, carbohydrates, vitamins, calcium, water, or daily menu changes)?

- Did the health workers ever explain the importance of early breastfeeding and exclusive breastfeeding in the mother's pregnancy at this time?

- Did the health workers ever explain the benefits of family planning after giving birth during the current pregnancy?

In the data processing, each item above that was answered "yes" would be coded with 1 and "no" would be coded with 0 . The iron supplementation subvariable would be categorized as "implemented comprehensively" if from a total of 7 items of questions, the respondent answered at least 3-4 questions with "yes". Whereas for the antenatal counselling subvariable, from total 8 items of questions, if the respondents answered "yes" to at least four questions the subvariable would be categorized as "implemented comprehensively".

This questionnaire has been tested for validity and reliability. Based on the validity table, with a significant level of $5 \%$ and the number of respondents being 20 people, the $r$ table value was 0.444 . All statements fulfilled this requirement. The Cronbach Alpha value of this questionnaire was 0.906 .

The examination of hemoglobin levels was carried out to determine the prevalence of iron deficiency anemia in this region using $\mathrm{a} \mathrm{Hb}$ meter. The examination was done by taking capillary blood samples which would be placed on a strip that would read hemoglobin levels automatically. The validity of hemoglobin measurements using this tool was 0.909 for measurements through capillary blood samples (Ahmad et al., 2015), while the reliability value for the $\mathrm{Hb}$ meter was 0.80 (Pawlowski et al., 2015). Pregnant women with hemoglobin levels of less than $11 \mathrm{~g} / \mathrm{dl}$ were categorized as anemic (Silverberg, 2012).

The antenatal counseling program is carried out by health workers based on the Indonesian Ministry of Health guidance (Kemenkes RI, 2010). Health workers allowed time after the physical examination to provide information and discuss pregnancy related issues with the mothers. The information provided included: maternal health, healthy lifestyle, husband's role, danger signs in pregnancy, balanced nutrition, infectious and non-communicable diseases, exclusive breastfeeding, postpartum family planning, and immunization. In its implementation, the complete antenatal counseling was only carried out on the first visit (K1) for 20 minutes, while for the next visit it only focused on the complaints of pregnant women. In this study, the researchers did not conduct counseling interventions for the respondents. The researcher only conducted a process of evaluating the implementation of integrated antenatal care that was done by the health workers. This was carried out by distributing questionnaires to pregnant women who attended integrated antenatal care at Darul Imarah Health Center, so the results of the evaluation were based on the experience of respondents during their pregnancy check up using this health service. The researcher chose to use the recommendations of the Kemenkes (2010) as a guideline for making a questionnaire to examine antenatal counseling because this guideline was the only official guidance issued by the Indonesian Ministry of Health in supporting the implementation of antenatal counseling in the health center. 
Jurnal Keperawatan Soedirman 14 (3) 2019 : 145 - 154

The analysis of the relationship between iron supplementation and antenatal counseling with iron deficiency anemia was performed using the Pearson Product Moment test.

\section{RESULTS}

Table 1 showed the demographic characteristics of respondents which was demonstrated by more than $2 / 3$ of respondents at no-risk age (26-35 years old), half of the respondents' highest level of education was in the middle category, almost all of them were housewives, and $2 / 3$ of the total respondents had an income of less than IDR2.700,000/month.

\begin{tabular}{|c|c|c|}
\hline Characteristics & & \\
\hline \multirow{2}{*}{\multicolumn{3}{|c|}{ Age }} \\
\hline & & \\
\hline Risk & 16 & 15.7 \\
\hline Not Risk & 86 & 84.3 \\
\hline \multicolumn{3}{|l|}{ Last Education } \\
\hline Low & 20 & 19.6 \\
\hline Middle & 60 & 58.8 \\
\hline High & 22 & 21.6 \\
\hline \multicolumn{3}{|l|}{ Job } \\
\hline Housewives & 100 & 98.0 \\
\hline Entrepreneur & 1 & 1.0 \\
\hline Teacher & 1 & 1.0 \\
\hline \multicolumn{3}{|l|}{ Family income } \\
\hline \multirow{2}{*}{$\begin{array}{l}\geq \text { Rp2.700.000/month } \\
<\text { Rp2.700.000/month }\end{array}$} & 34 & 33.3 \\
\hline & 68 & 66.7 \\
\hline
\end{tabular}

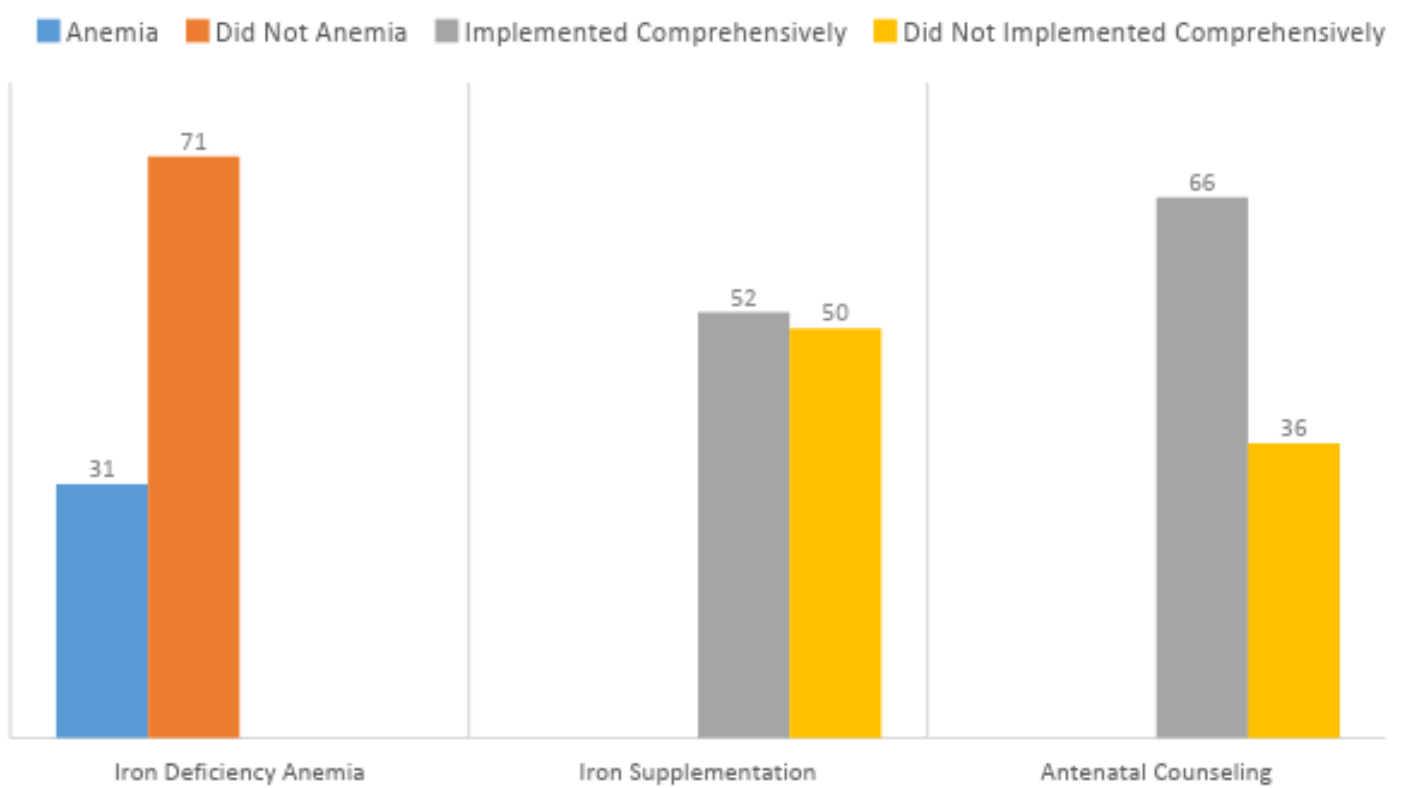

Graph. 1 The frequency distribution of iron deficiency anemia, implementation of iron supplementation and antenatal counseling

The prevalence of iron deficiency anemia in Darul Imarah Public Health Center in Aceh Besar District was 30.4\%. The implementation of iron supplementation and antenatal counseling was implemented comprehensively (52.0\% and $66 \%$ respectively) (Graph 1 ).

Table. 3 The relationship between the implementation of iron supplementation and iron deficiency anemia in Darul Imarah Public Health Center, Aceh Besar District

\begin{tabular}{|c|c|c|c|c|c|c|c|c|}
\hline \multirow{3}{*}{ No } & \multirow{3}{*}{ Iron Supplementation } & \multicolumn{4}{|c|}{ Iron Deficiency Anemia } & \multirow{3}{*}{ Total } & \multirow{3}{*}{$\alpha$} & \multirow{3}{*}{$p$-value } \\
\hline & & \multicolumn{2}{|c|}{ Anemia } & \multicolumn{2}{|c|}{ Did Not Anemia } & & & \\
\hline & & f & $\%$ & $f$ & $\%$ & & & \\
\hline 1 & Implemented Comprehensively & 2 & 3.8 & 50 & 96.2 & 52 & & \\
\hline 2 & Not Implemented Comprehensively & 29 & 58.0 & 21 & 42.0 & 50 & 0.05 & 0.000 \\
\hline & Total & 31 & 30.4 & 71 & 69.6 & 102 & & \\
\hline
\end{tabular}


From the results above, it shows there was a correlation coefficient between the implementation of iron supplementation and the prevalence of iron deficiency anemia, which was 0.589 , with a significancy of $=0.000$. Based on decision criteria, it can be concluded that the correlation of the two variables is significant because the significant value that accompanies it is smaller than 0.05 . So it was statistically concluded that there was a relationship between the implementation of iron supplementation and iron deficiency anemia in the Darul Imarah Public Health Center in Aceh Besar District.

Table. 4 The relationship between antenatal counseling and iron deficiency anemia in Darul Imarah Public Health Center, Aceh Besar District

\begin{tabular}{|c|c|c|c|c|c|c|c|c|}
\hline \multirow{3}{*}{ No } & \multirow{3}{*}{ Antenatal Counseling } & \multicolumn{4}{|c|}{ Iron Deficiency Anemia } & \multirow{3}{*}{ Total } & \multirow{3}{*}{$\alpha$} & \multirow{3}{*}{ p-value } \\
\hline & & \multicolumn{2}{|c|}{ Anemia } & \multicolumn{2}{|c|}{ Did Not Anemia } & & & \\
\hline & & $\mathbf{f}$ & $\%$ & $f$ & $\%$ & & & \\
\hline 1 & Implemented Comprehensively & 17 & 25.8 & 49 & 74.2 & 66 & & 179 0 \\
\hline \multirow[t]{2}{*}{2} & Not Implemented Comprehensively & 14 & 38.9 & 22 & 61.1 & 36 & 5 & $0.1 / 2$ \\
\hline & Total & 31 & 30.4 & 71 & 69.6 & 102 & & \\
\hline
\end{tabular}

From the results above, it shows there was a correlation coefficient between the implementation of antenatal counseling and the prevalence of iron deficiency anemia, which was 0.136 , with a significancy of $=0.172$. Based on decision criteria, it can be concluded that there was no statistical relationship between the two variables and the correlation was very weak. So it can be concluded that there was no statistical relationship between the implementation of antenatal counseling and iron deficiency anemia in Darul Imarah Public Health Center, Aceh Besar District.

\section{DISCUSSION}

This study was different from previous studies that have been conducted because we tried to assess the relationship between government programs that have been applied so far with the incidence of iron deficiency anemia in order to know if there was any significant impacts of the government program on the incidence of iron deficiency anemia.

Basically, the implementation of iron-tablet supplementation programs for pregnant women has been included in the standard of antenatal care in Indonesia since 1975 (Triyani \& Purbowati, 2016). The supplements that are usually given are in the form of tablets with ferrous sulphate (Silverberg, 2012).

The results of this study are supported by previous research conducted by Lesilolo, Engka, \& Wungouw (2016) who found that there was a relationship between the administration of iron tablets and hemoglobin levels in pregnant women in Bolaang Mangondouw Utara District ( $p$ value $=0.015$ ). In addition, other research conducted by Schoorl, Schoorl, van der Gaag, \& Bartels (2012) in Netherlands found that the hemoglobin concentration in pregnant women increased from $10.5 \mathrm{gr} / \mathrm{l}$ to $11.5 \mathrm{gr} / \mathrm{l}$ after iron supplementation $(\mathrm{p}$ value $\leq 0.001$ ). Similar studies have also been carried out in other age groups, for example - a study of adolescent girls found that the consumption of iron supplements in anemic adolescents had a significant impact on reducing the incidence of anemia. The average decrease in this incidence was $24.9 \%$ (Arini, Bakta, \& Citrawati, 2017).

Anemia is a physiological condition in pregnant women that occurs because of an increase of blood volume by $40 \%$, but the increase of red blood cell mass is only $15-20 \%$. This is a body mechanism to meet the supply of blood flow to the fetus. However, this condition decreases the hemoglobin concentration of the maternal blood (Yehuda \& Mostofsky, 2010). In an effort to prevent anemia, pregnant women are recommended to consume iron tablets. This tablet contains an amount of iron which can be absorbed by the body and would be a source of iron for the maternal body. The number of tablets that should be consumed by pregnant women based 
on the recommendation by Kemenkes $\mathrm{RI}$ (2010) is 90 tablets during pregnancy. This number suits the mother's needs because pregnant women need about $60 \mathrm{mg}$ of iron from the beginning of pregnancy $(\mathrm{WHO}$, 2001). This is the existing evidence that strengthens the findings of this study that giving iron tablets during antenatal care will reduce the incidence of iron deficiency anemia in pregnant women.

Apart from giving iron tablets during antenatal care, iron deficiency that occurs in pregnancy is also caused by inadequate nutritional intake (Gluckman, Hanson, Seng, \& Bardsley, 2015). Iron absorption also depends on the type of food consumed along with the consumption of the tablet because there are several foods that can either increase or inhibit iron absorption (Garrison, 2009; Yehuda \& Mostofsky, 2010). Pregnant women must also receive information related to the benefits, substances contained in a tablet, and side effects from the tablet so it is important to provide additional information to pregnant women when the mother is given a prescription for iron tablets (Department of Health Western Australia, 2015).

The effective communication, information and education that is given during antenatal counseling has been one of the standards in antenatal care since 2010. This standard has undergone a renewal since the initial concept which was only counseling or talking about the preparation of referrals (Departemen Kesehatan RI, 2007). Effective antenatal counseling includes giving various information that is carried out from the first contact to help pregnant women to resolve problems. The information recommended by Kemenkes RI (2010) to be delivered to pregnant women during antenatal care includes: maternal health, hygienic and healthy living behavior, the role of husband / family in pregnancy and planning of childbirth, balanced nutritional intake, early breastfeeding initiation, exclusive breastfeeding, and family planning.

The results found in this study contradict the research conducted by Bara, Fanny, \& Wijayanagara (2015) who found that there were differences in the average hemoglobin level in pregnant women who received counseling and who did not receive counseling ( $p$-value = 0.000 ). This study conducted 3 counseling sessions for pregnant women with a duration of 30-45 minutes per session.

Other research conducted by Susheela, Gupta, \& Mondal (2016) that was concerned with the effect of counseling on the incidence of anemia in young women shows that there was a significant increase in hemoglobin levels from $<12 \mathrm{gr} / \mathrm{dl}$ to $12-14.4 \mathrm{gr} / \mathrm{dl}$ after counseling. The follow-up process at the 6 th month showed the incidence of anemia decreased from $3 \%$ to $1 \%$. The counseling intervention carried out in this study contained information about dietary habits, including cooking recipes and recommended food servings.

The results obtained from this study contradict the results from the two studies mentioned above. This difference in the results could have occurred because the information delivery recommended by Kemenkes $R I$ (2010) is for the general condition of pregnancy therefore it is not suitable for delivering to pregnant women with anemia. The explanation regarding good nutrition is only one small part of the overall counseling material that should be delivered. This means the information about nutrition cannot be delivered in detail, which is unsuitable for pregnant women with anemia. The total respondents who reported receiving information about nutrition were 85 respondents (83.3\%).

Furthermore, the process of implementing the antenatal counseling is carried out at the same time as other antenatal examinations. So, it means a lot of actions and information must be delivered during one visit, which means that the counseling process is carried out hastily. It differs from the counseling conducted by Bara, Fanny, \& Wijayanagara (2015) where the counseling was carried out for 3 session with duration a duration of 30-45 minutes per session.

The submission of information regarding pregnancy carried out at public health centers is usually only done once at 
the mother's first visit to antenatal care. Information that is only delivered once without reinforcement means it is difficult to understand by the recipients and it is not internalized in their life. The research conducted by Bara, Fanny, \& Wijayanagara (2015) proved that conducting one counseling session cannot solve the problem of anemia in pregnancy. The researcher examined hemoglobin levels after the first session of counseling was completed. The results showed there was no significant difference in hemoglobin levels in the group given the counseling intervention with the control group ( $p$-value $=0.918$ )

One of the pieces of health information given in the implementation of antenatal counseling was the husband's support for pregnant women during pregnancy and childbirth. Qualitative research conducted by oleh Setyobudihono, Istiqomah, \& Adiningsih (2016) found that the husband played an important role in influencing his wife to consume iron tablets. However, in the phenomenon observed by the researcher, the implementation of antenatal counseling is rarely given to the husband. If the information about the husband's role in pregnancy is given to pregnant women only, then the benefits of this information will not be as good as if it was delivered directly to the husband. In this study, it was found that as many as 86 respondents (84.3\%) received information about the husband's role in pregnancy.

\section{CONCLUSION AND RECOMMENDATION}

Based on the results of this study and the discussion above, it was concluded that the implementation of iron supplementation was associated with iron deficiency anemia, while the implementation of antenatal counseling was not associated with iron deficiency anemia. Antenatal service providers are expected to be able to improve the quality of services provided, especially regarding the continuity of giving iron supplementation accompanied by providing information and support through antenatal counseling. It is also recommended that stakeholders be able to make a new version of integrated antenatal counseling implementation, where it is hoped that counseling can be carried out at a separate time from the routine pregnancy examinations, so that the opportunity to give information to pregnant women is maximized as much as possible. Although the implementation of the 10T antenatal care program includes the counseling about iron tablets, these parts are only small parts that are deemed insignificant. Therefore, making a new guidance for counseling more specifically is something that can be considered.

\section{REFERENCES}

Ahmad, N. A., Awaluddin, M., Samad, R., Kasim, N. M., Yusof, M., Razak, M. A., Sahril, N. (2015). Validity of point-of-care testing mission plus in detecting anemia. International Journal of Biomedicine, 5(2), 91-94.

Arini, N., Bakta, M., \& Citrawati, D. M. (2017). The impact of iron supplementation toward hemoglobin levels on teenage girls in Bangli regency, Bali, Indonesia. International Journal of Research in Medical Sciences, 5(8), 3454-3457.

Bara, F. T., Fanny, L., \& Wijayanagara, H. (2015). Pengaruh konseling gizi pada ibu hamil dengan anemia terhadap status gizi di Kecamatan Minasatene dan Kecamatan Pangkajene Kabupaten Pangkajene. Jurnal IImiah Kesehatan, 6(2), 253262.

Cantor, A. C., Bougatsos, C., Dana, T., Blazina, I., \& Mcdonagh, M. (2015). Annals of Internal Medicine Routine Iron Supplementation and Screening for Iron Deficiency Services Task Force. Annals of Internal Medicine, 162(8), 566-576.

Chhabra, P. (2014). Maternal near miss: $\mathrm{An}$ indicator for maternal health and maternal care. Indian Journal of Community Medicine, 39(3), 132137. 
Clarke, L., \& Dodds, A. J. (2014). Iron deficiency anaemia: Cause, symptoms and treatment. Medicine Today, 15(11), 36-42.

Daru, J., Zamora, J., Fernández-félix, B. M., Vogel, J., Oladapo, O. T., Morisaki, N., ... Torloni, M. R. (2018). Articles Risk of maternal mortality in women with severe anaemia during pregnancy and post partum: a multilevel analysis. The Lancet, 6, 548-554.

Departemen Kesehatan RI. (2007). Pedoman pelayanan antenatal. Jakarta: Departemen Kesehatan RI.

Department of Health Western Australia. (2015). Complications in pregnancy: Anemia. Retrieved February 11, 2018, from http://www.kemh.health. wa.gov.au/development/manuals/O\& G_guidelines/sectionb/2/b2.23.pdf

Dinas Kesehatan Kabupaten Aceh Besar. (2016). Profil kesehatan Kabupaten Aceh Besar tahun 2015. Aceh: Dinas Kesehatan Kabupaten Aceh Besar.

Garrison, C. (2009). Anemia: A symptom, not a diagnosis (Ed. 2). USA: Sourcebooks, Inc.

Gluckman, P., Hanson, M., Seng, C. Y., \& Bardsley, A. (2015). Nutrition and lifestyle for pregnancy and breastfeeding. United Kingdom: Oxford University Press.

Inter-Agency and Expert Group on SDG Indicators. (2016). Final list of proposed sustainable development goal indicators. Retrieved December 21, 2017, from https://sustainable development.un.org/content/docume nts/11803Official-List-of-ProposedSDG-Indicators.pdf

\section{Kemenkes RI. (2010). Pedoman Pelayanan Antenatal Terpadu. Jakarta: Direktur Jenderal Bina Kesehatan Masyarakat Kementerian Kesehatan Republik Indonesia.}

Kemenkes RI. (2013). Riset kesehatan dasar 2013. Jakarta: Badan Penelitian dan Pengembangan Kementerian Kesehatan RI.

Kemenkes RI. (2016). Profil kesehatan Indonesia 2015.2 Jakarta: Kementerian Kesehatan Republik Indonesia.

Lesilolo, T. N., Engka, J., \& Wungouw, H. (2016). Hubungan pemberian tablet besi dan antenatal care terhadap kadar hemoglobin pada ibu hamil di Kabupaten Bolaang Mangondouw Utara. Jurnal E-Biomedik, 4(1).

Pawlowski, M., Latute, F., BardouJacquet, E., Latournerie, M., Zerrouki, S., Bendavid, C., Ropert, M. (2015). Portable hemoglobinometer is a reliable technology for the follow-up of venesections tolerance in hemochromatosis. Clinics and Research in Hepatology and Gastroenterology, 39(5), 570-575.

Porwit, A., McCullough, J., \& Erber, W. N. (2011). Blood and bone marrow pathology (Ed. 2). New York: Churchill Livingstone Elsevier.

Schoorl, M., Schoorl, M., van der Gaag, D., \& Bartels, P. C. M. (2012). Effects of iron supplementation on red blood cell hemoglobin content in pregnancy. Hematology Reports, 4(4), 91-94.

Setyobudihono, S., Istiqomah, E., \& Adiningsih, S. (2016). Husband influences on pregnant women who following consumption iron supplementation program. Procedia - Social and Behavioral Sciences, 222, 160-168.

Silverberg, D. S. (2012). Anemia. Croatia: InTech.

Sivanganam, S., \& Weta, W. (2017). Gambaran tingkat kepatuhan ibu hamil mengkonsumsi tablet besi di wilayah kerja puskesmas Sidemen 
tahun 2015. Intisari Sains Medis, 8(2), 135-138.

Susheela, A. K., Gupta, R., \& Mondal, N. K. (2016). Anaemia in adolescent girls: An intervention of diet editing and counselling. National Medical Journal of India, 29(4), 200-204.

Triyani, S., \& Purbowati, N. (2016). Kepatuhan konsumsi tablet $\mathrm{Fe}$ dalam mencegah anemia gizi besi pada ibu hamil di wilayah Puskesmas Kecamatan Jakarta
Pusat. Jurnal IImu Dan Teknologi Kesehatan, 3(2), 215-229.

Vir, S. C. (2011). Public Health Nutrition in Developing Countries. New Delhi: Woodhead Publishing India Pvt. Ltd.

WHO. (2001). Iron deficiency anaemia: Assessment, prevention and control. Geneva: World Health Organization.

Yehuda, S., \& Mostofsky, D. (2010). Iron deficiency and overload from basic biology to clinical medicine. United States: Humana Press. 